\title{
The Impacts of Perceived Crowding, and Atmospherics on Visitor Satisfaction at Cultural Heritage Sites: A Comparison of Turkish and British Visitors to Topkapi Palace, Istanbul
}

\author{
Doğuş Kılıçarslan \\ Akdeniz University, Antalya \\ Meltem Caber \\ Akdeniz University, Antalya
}

Received January 17 2018; received in revised form 17 November 2018; accepted 10 December 2018

\begin{abstract}
Cultural heritage sites impress the visitors by their 'worth-to-see' architectural characteristics, and historical or cultural importance. Visitor experiences at cultural areas are also influenced by site atmospherics, and crowd, that form visitors' overall satisfaction with site. The main objectives of this study, therefore, are: (1) to reveal perceived crowding, atmospherics, and visitor satisfaction relationships at a cultural heritage site; and (2) to compare the crossnational differences in the sample of Turkish and British visitors. With this purpose, a survey was conducted at one of the most popular heritage sites of Turkey; Topkapi Palace, Istanbul. Data collected from 261 Turkish and 236 British visitors, who have seen the interior and exterior parts of the Palace. By factor analysis, atmospherics is found to have two dimensions, namely; service and spatial. Analyses results exhibit that both atmospherics dimensions positively affect visitor satisfaction, although perceived crowding has a negative impact or both nationalities. Findings of this study indicate that cultural heritage sites are the areas where domestic and foreign visitors may have similar kinds of perceptions and evaluations.
\end{abstract}

Keywords: Cultural tourism, heritage site, atmospherics, perceived crowding, satisfaction, Topkapi Palace, Istanbul.

\section{JEL Classification: Z3}

\section{Introduction}

In parallel to increasing competition, tourism destinations began to attempt to strengthen their positions in the global market by promoting unique or distinguishing attributes and assets that they have in comparison to others (Ayala, 1996). At this point, cultural assets may be particularly emphasized in order to highlight the attractiveness of a destination. In particular, cultural heritage sites may generate memorable visitor experiences. In this context, site atmospherics and its additional components such as good lighting, signage, audio tours, etc. should be designed and controlled by professional perspectives. If 
these factors are managed effectively, visitor experiences and overall satisfaction are expected to be increased (Bonn et al., 2007; Dietsch, 1997). Likewise, previous studies in the tourism and travel literature show that atmospherics is a determinant of both visitor satisfaction (Yildirim \& Akalin-Baskaya, 2007), and brand image (Baker, 1986; Bitner, 1992). Moreover, measurement attempts of overall visitor satisfaction have importance for the management of cultural assets (Kuo, 2002; McArthur, 1994; Moscardo, 1999; Orams, 1996). Although, atmospherics is important both for visitors' satisfaction and cultural site managers' success, existing literature consists a few number of studies that have investigated this topic.

Crowd perception is another determinant of overall satisfaction and behavioural intention of cultural heritage site visitors. The perception of crowding mostly varies depending on the location, activity, and number of the people (Desor, 1972). While the perception of crowding in bars and stadiums is found to affect people in a positive way, in some other locations, such as shopping malls, people are negatively affected by crowds in their purchasing decisions or length of stay at a shop (Hui \& Bateson, 1991; Machleit et al., 2000). In the literature, only a limited number of studies examine the relationship between crowd perception and visitor satisfaction (Lee, 1977; Shelby, 1980; Tseng et al., 2009). In those studies, some researchers have linked crowding with carrying capacity in recreational areas (Manning, 1999), and visitor experiences in wilderness (Cole, 2001). However, the relationship between cultural site visitors' crowd perceptions and their satisfactions has scarcely been examined in the tourism and travel literature.

The main objectives of this study, therefore, are: (1) to reveal perceived crowding, atmospherics, and visitor satisfaction relationships at a cultural heritage site; and (2) to compare the cross-national differences in the sample of Turkish and British visitors. By a survey performed at Topkapi Palace in Istanbul, Turkey, those objectives are examined and the obtained results are discussed by the authors. Findings of this study have the potential of contribution to the limited literature particularly on crowding perception, which is considered an important element of visitor management at cultural heritage areas. To the best of the authors' knowledge, this study is also one of the early attempts that examine the relationships among the research variables. In the next section, a literature review is presented about the constructs of atmospherics, crowding perception, and visitor satisfaction. Following this, the research setting of Topkapi Palace is briefly introduced. Afterwards, research methodology is introduced, and analysis results are summarized. The paper concludes with a discussion of findings, limitations, and future research recommendations.

\section{Literature Review}

\subsection{Atmospherics}

The atmospherics phenomenon, which metaphorically alludes to the Earth's atmosphere, was first applied to the area of marketing by Kotler (1973). According to marketing point-of-view, people are influenced by some environmental factors called as atmospherics such as colours, sounds, other people, forms of exhibition, etc. in the process of purchasing decisions. Those factors affect people's purchasing and decision making behaviour either positively or negatively. In the field of marketing, researchers mostly focus on identifying the environmental factors that affect business atmosphere or examining the impact of atmosphere on customer behaviour. A study by Baker (1986) was a starting point for determining the factors that form atmospherics. In her study, Baker defined atmospherics as the 'service environment' and categorized the factors that generate atmospherics (layout, 
colours, complexity, etc.) as the social (employees), and ambience factors (lighting, voices, and smells). In another study, Bitner (1992) suggested that atmospherics can be measured by the evaluation of environmental conditions such as spatial order and functionality. In addition to these factors offered by Bitner (1992), Evans and Berman (1995) proposed the inclusion of external environment of a place (e.g., entrance, windows, exterior architecture). Tombs and McColl-Kennedy (2003) argued that studies on atmospherics generally involved the elements of physical environment, but ignored employees. They, therefore, recommended the inclusion of employee factor into atmospherics concept.

In the context of cultural tourism, physical environment that covers the cultural assets has a very wide scope (Bonn et al., 2007). Previous studies have shown that for visitors, who have a positive attitude towards the physical assets at a cultural site, revisit intention is usually high (Obermiller \& Bitner, 1984). According to Bonn et al. (2007), atmosphere of the cultural assets has influence both on visitor perception, and host destination's cultural entity. To sum up, atmospherics of cultural assets play a role on visitor behaviour and should be considered as a determinant of cultural tourist experiences.

\subsection{Crowding Perception}

The crowding concept is mainly examined theoretically in the context of environmental and behavioural psychology (Neuts \& Nijkamp, 2012). There are two basic theories in this context. One suggests that an individual's crowding perception is a kind of behavioural restraint and stimulus load (Kaya \& Weber, 2003), which is an inappropriate or unwanted social communication. According to this perspective, crowding perception emerges when an individual is overwhelmed by the presence of others, resulting in an increase in social interest and environmental intensity (Desor, 1972). According to second perspective, crowding is perceived, when other people intervene an individual's experience (Stokols, 1972). Neuts and Nijkamp (2012) associated the crowding construct with carrying capacity and sustainability issues. For these researchers, the perception of crowding originates by exceeding socio-cultural carrying capacity. However, crowd perception does not simply occur because of human density. There are also other factors that play decisive roles on people's crowding perception (Stokols et al., 1973). For example, Stokols (1972) noted that perceived crowding is related to physical congestion in the environment, which psychologically affects people. Stokols et al. (1973) also underlined that perception level varies depending on the size, breadth, and ambience of objects in the environment, as well as on some social factors.

Other researchers have stated that perceived crowding is not formed only by human density and congestion, but also by preferences, anticipation, area types, and environmental characteristics (Graefe et al., 1984; Manning et al., 2000). Eventually, perceived crowding is a behavioural variable that is supposed to have influence on cultural site visitors' quality of experience; this in turn is closely related to visitor management strategies regarding carrying capacity and sustainability issues.

\subsection{Visitor Satisfaction}

Visitor satisfaction is one of the most investigated research topics in the tourism and travel literature. In previous studies, scholars generally have aimed to explore overall satisfaction with a destination, whereas few studies to date have examined visitor satisfaction with cultural assets (Prayag \& Chiappa, 2016). While customer satisfaction in the marketing field indicates a general assessment of products and services, depending on purchasing and 
consumption experiences (Anderson et al., 1994), visitor satisfaction in the context of tourism and travel involves an emotional response to a specific visit experience (Bosque \& Martín, 2008).

Some researchers have suggested that satisfaction means the meeting of needs, while others have argued that it is a process influenced by psychological conditions (Tian-Cole \& Cromption, 2003). Researchers in the second group, therefore, benefit from the psychological states and habits of individuals while addressing the socio-psychological processes that represent satisfaction (Mannell \& Kleiber, 1977). Brown (1988) suggested that satisfaction consists of experiences that people willingly feel under any obligation.

Nykiel (1997) stated that visitor satisfaction is influenced by many service encounters during the period of an experience. However, Kozak and Rimmington (2000) argued that visitor satisfaction is a general evaluation about the features in a destination. In many studies, visitor satisfaction has been found to contribute to management success and strategies (e.g., Kuo, 2002; McArthur, 1994; Moscardo, 1999; Orams, 1996). Thus, destination authorities should try to evaluate and increase visitors' satisfaction (Wu \& Li, 2015)

\section{Research Setting: Topkapi Palace, Istanbul}

Construction of Topkapi Palace began in 1460 and was completed in 1478. The palace was built upon an area of 700,000 square meters on an Eastern Roman Acropolis located on the Istanbul Peninsula between the Sea of Marmara, the Bosphorus, and the Golden Horn. Topkapi Palace was the administrative, educational, and art centre of the Ottoman Empire for nearly four hundred years, from the age of Mehmed until Sultan Abdulmecid, who was the thirty-first of the sultans. Although the palace was abandoned by the Ottoman Dynasty after the establishment of Dolmabahce Palace in the middle of the 19th century, Topkapi Palace prolonged its importance and attraction for local and foreign visitors (Topkap1 Palace Museum Directorate 2016).

Topkapi Palace was transformed into a museum on April 3, 1924 after the establishment of the Republic of Turkey. It thus became the first museum of the new country. Today, the palace occupies an area of approximately 400,000 square meters and is one of the largest palace museums in the world, with architectural structures, collections, and 300,000 archival documents. It is the second most visited museum in Turkey, following the Haghia Sophia Museum. Topkapi Palace is also registered and protected as one of the UNESCO World Heritage sites in Turkey.

\section{Methodology}

In this study, a research model is proposed that aims to test the relationships among atmospherics, visitor crowding perception, and visitor satisfaction. In the model, although atmospherics are suggested to have a positive effect on visitor satisfaction, the relationship between crowding perception and satisfaction is proposed to be negative. A correlative and negative relationship is also presumed between atmospherics and crowding perception as illustrated by Figure 1.

$\mathrm{H}_{1}$ : Atmospherics have a positive impact on visitor satisfaction.

$\mathrm{H}_{2}$ : Crowding perception has a negative impact on visitor satisfaction.

$\mathrm{H}_{3}$ : Crowding perception and atmospherics are negatively correlated. 


\section{Research Model}

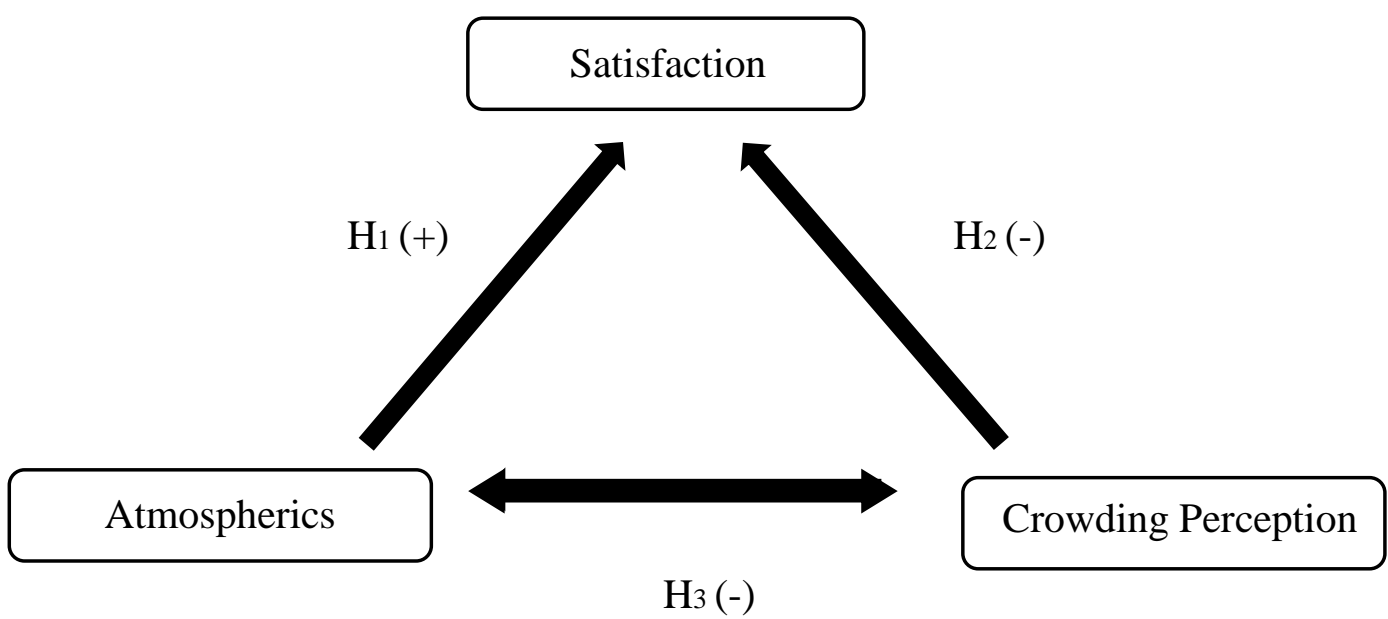

Source: Authors

\subsection{Sample and Data Collection}

Survey technique is preferred by the authors to identify the statistical relationships among the research variables, in which the data were collected from Turkish and British visitors to Topkapi Palace, Istanbul. The original questionnaire in English was translated into Turkish so that it could be answered by both participant groups. A back translation was additionally performed to check the comprehensiveness of the items and to detect any translation mistakes. The final version of the questionnaire (see Appendix 1) is structured in four parts, which identify and measure participant demographics, crowding perceptions, atmospherics, and satisfactions. In the first part, demographic characteristics of the participants are determined by 12 questions. In the second part, items that measure atmospherics are obtained from Bonn et al.'s (2007) study, and in the third part, visitor satisfaction is measured by a five-item semantic differential scale adapted from a study conducted by Rojas and Camarero (2007). Finally, crowding perception is measured by two items obtained from the studies of Shelby, Vaske, and Heberlein (1989), and Neuts and Nijkamp (2012).

Convenience sampling method is preferred in data collection, since it enables researchers to select the units that can be reached with the least cost in the shortest time (Özmen, 2006). The target sample consisted of Turkish and British visitors who visited the interior and exterior parts of the Palace. Data were collected from 512 individuals (242 British and 270 Turkish visitors) in August-September 2016. After the elimination of incomplete questionnaires, the final sample comprised 497 responses, of whom 236 were from British and 261 were from Turkish visitors. 


\subsection{Normality and Reliability Analysis}

In the analysis of the reliability, skewness and kurtosis values were firstly examined to determine whether the data show a normal distribution. Skewness and kurtosis values ranged between -1.393 and +1.543 . Thus, the data were considered to be normally distributed, while Tabachnick and Fidell (2013), and George and Mallery (2010) recommend the skewness and kurtosis values between -2.0 and +2.0 for a normal data distribution.

Cronbach's alpha coefficients were then calculated for each of the variables with the aim of determining individual reliabilities. The coefficient was 0.92 for atmospherics, and 0.94 for satisfaction constructs. These values were higher than the recommended cut off value of 0.70, and thus, the used scales were reliable. Cronbach's alpha coefficient belongs to perceived crowding was found as 0.58 . Although, this is a relatively low value than the other constructs', it was considered as reliable, since the value was close to Cronbach's alpha value of 0.60 which was suggested acceptable by Churchill (1979). The results of the reliability analysis for each of the variables showed that collected data were appropriate for further analyses.

\section{Results}

\subsection{Participant Demographics}

Demographic characteristics of the participants are shown in Table 1. Of the total sample (497), 261 (52.5\%) were Turkish and 236 (47.5\%) were British. Gender distribution showed nearly equal shares for males and females: $51.7 \%$ of Turkish participants were males and $48.3 \%$ were females, although among British participants $55.5 \%$ were males and $44.5 \%$ were females.

Table 1

Demographic characteristics of the participants

\begin{tabular}{|c|c|c|c|c|c|c|}
\hline \multirow[b]{2}{*}{ Demographics } & \multicolumn{2}{|c|}{ Turkish } & \multicolumn{2}{|c|}{ British } & \multicolumn{2}{|c|}{ General } \\
\hline & $\begin{array}{c}\text { Frequency } \\
\text { (f) }\end{array}$ & $\%$ & $\begin{array}{c}\text { Frequency } \\
\text { (f) }\end{array}$ & $\%$ & $\begin{array}{c}\text { Frequency } \\
\text { (f) }\end{array}$ & $\%$ \\
\hline \multicolumn{7}{|l|}{ Gender } \\
\hline Male & 135 & 51.7 & 131 & 55.5 & 266 & 53.5 \\
\hline Female & 126 & 48.3 & 105 & 44.5 & 231 & 46.5 \\
\hline \multicolumn{7}{|l|}{ Age } \\
\hline 20 and younger & 45 & 17.2 & 19 & 8.1 & 64 & 12.9 \\
\hline $21-30$ & 115 & 44.1 & 113 & 47.9 & 228 & 45.9 \\
\hline $31-40$ & 54 & 20.7 & 59 & 25.0 & 113 & 22.7 \\
\hline $41-50$ & 37 & 14.2 & 24 & 10.2 & 61 & 12.3 \\
\hline 51 and older & 10 & 3.8 & 21 & 8.9 & 31 & 6.2 \\
\hline \multicolumn{7}{|l|}{ Marital Status } \\
\hline Married & 114 & 43.7 & 110 & 46.6 & 224 & 45.1 \\
\hline
\end{tabular}




\begin{tabular}{lrrrrrr}
$\begin{array}{l}\text { Single } \\
\text { Profession/Job }\end{array}$ & 147 & 56.3 & 126 & 53.4 & 273 & 54.9 \\
$\quad$ Private Company & & & & & & \\
Employee & 64 & 24.5 & 86 & 36.4 & 150 & 30.2 \\
Employer & 40 & 15.3 & 30 & 12.7 & 70 & 14.1 \\
Student & 77 & 29.5 & 50 & 21.2 & 127 & 25.6 \\
Public Officer & 31 & 11.9 & 22 & 9.3 & 53 & 10.7 \\
Unemployed & 11 & 4.2 & 13 & 5.5 & 24 & 4.8 \\
Other & 38 & 14.6 & 35 & 14.8 & 73 & 14.7 \\
Education Level & & & & & & \\
Primary School & 2 & 0.8 & 0 & 0.0 & 2 & 0.4 \\
Middle School & 8 & 3.1 & 2 & 0.8 & 10 & 2.0 \\
High School & 71 & 27.2 & 14 & 5.9 & 85 & 17.1 \\
University & 172 & 65.9 & 201 & 85.2 & 373 & 75.1 \\
$\quad$ Other & 8 & 3.1 & 19 & 8.1 & 27 & 5.4 \\
Total & 261 & 52.5 & 236 & 47.5 & 497 & 100 \\
\hline
\end{tabular}

Source: Authors

The age group of $21-30$ was represented by $44.1 \%$ of Turkish participants and $47.9 \%$ of British participants. In general, $54.9 \%$ of the respondents were single and $45.1 \%$ were married. The marital status ratio was similar for both groups $(56.3 \%$ of Turkish $53.4 \%$ of British visitors were single; $43.7 \%$ of Turkish- $46.6 \%$ of British visitors were married).

\subsection{Factor Analysis Results for Atmospherics}

In the analysis of atmospherics factorial structure, firstly, the KMO (Kaiser-MeyerOlkin) value was used to determine the sufficiency of data. The value of 0.915 showed that data were suitable for analysis, compared to the value of 0.60 or greater recommended by Büyüköztürk (2016). Bartlett Sphericity Test $(p=0.00)$ results also showed that there was a significant relationship between the construct dimensions. Secondly, for obtaining the dimensions of atmospherics, 11 items were included in the explanatory factor analysis by using Varimax rotation method. The variance explanation ratio was $66.93 \%$, with two factors having eigenvalues above than the recommended value of 1.00 . The analysis results are shown in Table 2. Although, earlier studies (Baker, 1986; Bonn et. al., 2007) had offered three factors to explain cultural assets' atmospherics, the present study's results offered a twofactorial solution. The dimensions of ambiance and design-classification, from the original scale, were grouped under a single dimension in this study and named as 'spatial atmosphere'. Another factor was renamed, from 'social service environment' in the original scale to 'service atmosphere' in the present study.

Service atmosphere consisted of four items as shown in Table 2. Eigenvalue of the service factor was 3.682, and the explained variance ratio was $57.30 \%$. The Cronbach's alpha coefficient, used to test the internal consistency of this factor, was found to be 0.90 . Spatial atmosphere contained seven items as presented in Table 2. Eigenvalue of the spatial factor was 3.680, the explained variance ratio was $9.62 \%$, and Cronbach's alpha was 0.87 which is above the recommended cut-off value. 
Table 2

Factorial structure of atmospherics

\begin{tabular}{lcccc}
\hline Factors/Items & $\begin{array}{c}\text { Factor } \\
\text { Loading }\end{array}$ & $\begin{array}{c}\text { Eigen- } \\
\text { value }\end{array}$ & $\begin{array}{c}\text { Means } \\
\text { (M) }\end{array}$ & $\begin{array}{c}\text { Cronbach's } \\
\text { Alpha }\end{array}$ \\
\hline $\begin{array}{l}\text { Factor 1: Service Atmosphere } \\
\quad \text { Topkapi Palace has a good staff }\end{array}$ & 0.866 & 3.682 & 4.85 & 0.90 \\
$\quad$ The staff at the Topkapi Palace is courteous & 0.835 & & & \\
$\quad$ The staff at the Topkapi Palace are very & 0.826 & & & \\
knowledgeable & 0.756 & & \multirow{2}{*}{6.21} & \\
$\quad$ Topkapi Palace offers good service & & 3.680 & & \\
Factor 2: Spatial Atmosphere & 0.824 & & & \\
$\quad$ Topkapi Palace has a good color scheme & 0.791 & & & \\
$\quad$ Topkapi Palace has good lighting & 0.693 & & \\
$\quad$ Topkapi Palace has good signage and availability of & & & \\
information & & & \\
$\quad$ Topkapi Palace has a good functional layout & 0.680 & & \\
$\quad$ Topkapi Palace has a good use of open space & 0.624 & & \\
$\quad$ Topkapi Palace has a good flow of customer traffic & 0.591 & & \\
$\quad$ It is easy to find the way around the Topkapi Palace & 0.558 & & \\
\hline
\end{tabular}

Kaiser-Meyer-Olkin: 0.915 Total Average Variance Extracted (AVE) 66.93\%

Bartlett Sphericity Test: 3484.274 df= 55 Sig. 0.000

Source: Authors

\subsection{Test of the Hypotheses}

For testing the study hypotheses, regression and correlation analyses were performed between the constructs, starting with atmospherics and satisfaction. In the first regression analysis, visitor satisfaction was the dependent variable, and the dimensions of atmospherics (spatial and service) were the independent variables.

The impact of atmospherics on satisfaction

Table 3

\begin{tabular}{lcccc}
\hline Independent Variables & $\begin{array}{c}\text { Unstandardized Beta } \\
\text { Coefficient }\end{array}$ & $\begin{array}{c}\text { Standard } \\
\text { Error }\end{array}$ & $\begin{array}{c}\text { Standardized Beta } \\
\text { Coefficient }\end{array}$ & $\boldsymbol{p}$ \\
\hline Constant & 1.66 & 0,22 & - & $0.00^{*}$ \\
Service Atmosphere & 0.17 & 0,05 & 0.17 & $0.00^{*}$ \\
Spatial Atmosphere & 0.58 & 0,06 & 0.49 & $0.00^{*}$ \\
\hline
\end{tabular}

${ }^{*} \mathrm{p}<0.01 ; \mathrm{R}=0,63 ; \mathrm{R}^{2}=0,39 ; \mathrm{F}=159,064 ; \mathrm{p}=0.00$

Source: Authors

Results (Table 3) indicated that the regression model was significant at the 0.01 level. The dimension of atmospherics explained $39 \%$ of visitor satisfaction, with positive and significant effects shown for service atmosphere and spatial atmosphere. Standardized beta values showed that the spatial atmosphere dimension $(\beta=0.49)$ had a higher effect on visitor 
satisfaction than the service atmosphere dimension $(\beta=0.17)$. Thus, the first hypothesis $\left(\mathrm{H}_{1}\right.$ : Atmospherics have a positive impact on visitor satisfaction) was accepted.

Results for the regression model showing the impact of the perception of crowding on visitor satisfaction are shown in Table 4. In this analysis, satisfaction was used as the dependent variable, and crowding perception was used as the independent variable.

The model was statistically significant at the 0.01 level, with the perception of crowding explaining $2 \%$ of satisfaction, and a negative impact on satisfaction $(\beta=-0.14)$. Therefore, the second hypothesis $\left(\mathrm{H}_{2}\right.$ : Crowding perception has a negative impact on visitor satisfaction) was accepted.

Table 4

The impact of crowding perception on satisfaction

\begin{tabular}{lcccc}
\hline Independent Variables & $\begin{array}{c}\text { Unstandardized Beta } \\
\text { Coefficient }\end{array}$ & $\begin{array}{c}\text { Standard } \\
\text { Error }\end{array}$ & $\begin{array}{c}\text { Standardized Beta } \\
\text { Coefficient }\end{array}$ & $\boldsymbol{p}$ \\
\hline Constant & 5.97 & 0.17 & - & $0.00^{*}$ \\
Crowding perception & -0.12 & 0.04 & -0.14 & $0.00^{*}$ \\
\hline
\end{tabular}

${ }^{*} \mathrm{p}<0.01 ; \mathrm{R}=0,14 ; \mathrm{R}^{2}=0,02 ; \mathrm{F}=9,853 ; \mathrm{p}=0.00$

Source: Authors

To test the last hypothesis $\left(\mathrm{H}_{3}\right.$ : Crowding perception and atmospherics are negatively correlated), a correlation analysis was used. Results showed that a negative and low (-0.17) correlation exists between crowding perception and atmospherics. Thus, the third hypothesis was accepted.

\subsection{Test of the Group Differences}

After determining the impact of atmospherics on visitor perceptions, we aimed to understand whether there was a significant difference between Turkish and British visitors' perceptions. A t-test was used to examine any statistical differences, and the results are shown in Table 5.

Table 5

Perception differences in atmospherics

\begin{tabular}{lccccccc}
\hline $\begin{array}{l}\text { Dependent } \\
\text { Variables }\end{array}$ & Groups & $\begin{array}{c}\text { Frequency } \\
(\mathbf{F})\end{array}$ & $\begin{array}{c}\text { Standard } \\
\text { Deviation }\end{array}$ & $\begin{array}{c}\text { Means } \\
(\mathbf{M})\end{array}$ & $\mathbf{t}$ & df & Sig.(p) \\
\hline Service & Turkish & 261 & 1.51 & 4,83 & -.31 & 495 & 0.76 \\
Atmosphere & British & 236 & 1.55 & 4,88 & & & \\
& Turkish & 261 & 1.27 & 5,21 & .57 & 495 & 0.57 \\
Spatial Atmosphere & British & 236 & 1.26 & 5,14 & & & \\
General & Turkish & 261 & 1.26 & 5,07 & .22 & 495 & 0.82 \\
Atmosphere & British & 236 & 1.27 & 5,05 & & & \\
\hline
\end{tabular}

Source: Authors

While analysing the differences, the arithmetic means of both atmospherics dimensions (spatial and service) and general atmospherics were used as the dependent variable; nationalities were used as the independent variable. The t-test results showed no 
statistically significant difference between Turkish and British visitors' perceptions ( $\mathrm{p}>$ 0.05). For this reason, it was not necessary to examine the impact of atmospherics perception on satisfaction by nationality. We also investigated whether there was a difference between Turkish and British visitors with regard to the perception of crowding. The t-test results indicated a statistically significant difference between the two groups (Table 6).

Table 6

Crowding perception differences

\begin{tabular}{|c|c|c|c|c|c|c|c|}
\hline Dependent Variable & Groups & $\begin{array}{l}\text { Frequency } \\
\text { (F) }\end{array}$ & $\begin{array}{c}\text { Standard Deviation } \\
\text { (Std. Dev.) }\end{array}$ & $\begin{array}{c}\text { Means } \\
(\mathbf{M})\end{array}$ & $\mathbf{t}$ & df & Sig. $(p)$ \\
\hline \multirow{2}{*}{ Crowding perception } & Turkish & 261 & 1.79 & 4,26 & \multirow[b]{2}{*}{2.79} & \multirow[b]{2}{*}{495} & \multirow[b]{2}{*}{$0.01 *$} \\
\hline & British & 236 & 1.61 & 3,83 & & & \\
\hline
\end{tabular}

*p $<0.05$

Source: Authors

The statistically significant difference $(\mathrm{p}<0.05)$ showed that Turkish visitors' perception of crowding $(M=4.26)$ was higher than that of British visitors $(M=3.83)$. Consequently, a regression analysis was performed to examine the impact of crowding perception on satisfaction by nationality, with results shown in Table 7 . The model indicated that the perception of crowding for Turkish participants had no statistical significance on satisfaction $(p=0.29)$, but it did have such significance for British participants $(p=0.00)$, for whom the perception of crowding explained $7 \%$ of satisfaction, with a negative and significant effect $(\beta=-0.23)$.

Table 7

The impact of crowding perception on satisfaction by groups

\begin{tabular}{lccccc}
\hline Nationality & $\begin{array}{c}\text { Independent } \\
\text { Variables }\end{array}$ & $\begin{array}{c}\text { Unstandardized Beta } \\
\text { Coefficient }\end{array}$ & $\begin{array}{c}\text { Standard } \\
\text { Error }\end{array}$ & $\begin{array}{c}\text { Standardized Beta } \\
\text { Coefficient }\end{array}$ & $\begin{array}{c}\text { Sig. } \\
(\boldsymbol{p})\end{array}$ \\
\hline \multirow{3}{*}{ Turkish } & Constant & 5.852 & 0.242 & - & $0.00^{*}$ \\
& Crowding Perception & -0.056 & 0.052 & -0.66 & 0.29 \\
& $* \mathrm{p}<0.01 ; \mathrm{R}=0.07 ; \mathrm{R}^{2}=0.00 ; \mathrm{F}=1.145 ;$ & & & \\
\multirow{3}{*}{ British } & Constant & 6.236 & 0.236 & - & $0.00^{*}$ \\
& Crowding Perception & -0.239 & 0.057 & -0.265 & $0.00^{*}$ \\
& $* \mathrm{p}<0.01 ; \mathrm{R}=0.27 ; \mathrm{R}^{2}=0.07 ; \mathrm{F}=17.725 ;$ & & & \\
\hline
\end{tabular}

Source: Authors

In sum, results showed no significant difference in the perception of atmospherics between the groups. On the other hand, the perception of crowding differed by nationality: for British visitors, crowding had a negative impact on satisfaction, and for Turkish visitors there was no impact. 


\section{Discussion and Conclusion}

In the present study, cultural heritage site atmospherics, the perception of crowding, and overall visitor satisfaction relationships were examined, which have been the focus of few studies yet in the literature. Researchers have examined in previous studies either to atmospherics or perceived crowding (e.g., Moon et al., 2017; Zehrer \& Raich, 2016). However, to the best of our knowledge, in none of these studies site atmospherics and perceived crowding as well as their impacts on visitors' overall satisfaction have been investigated simultaneously. In addition, in most studies, research settings were the specific touristic areas or destinations rather than cultural heritage sites (e.g., Fakharyan et al., 2014; Rathnayake, 2015). In this context, this study and its findings have the potential of contributing to the existing literature by the clarification of the relationships among these variables with data obtained from a survey conducted in a UNESCO World Heritage site in Turkey. In many studies, visitor satisfaction was identified to contribute the success of site management plans and strategies (e.g., Kuo, 2002; McArthur, 1994; Moscardo, 1999; Orams, 1996). Thus, exploring the dimensions of atmospherics that satisfy or dissatisfy visitors may assist cultural site authorities' managerial decisions about the interior and exterior designs.

The results of this study showed that site atmospherics have a two sub-dimensions (service atmosphere and spatial atmosphere), despite the fact that earlier studies (Baker, 1986; Bonn et al., 2007) generally offered a three-dimensional structure (ambiance service environment, design and layout service environment, and social service environment). The dimensions, suggested as ambiance and design-classification in the original scale, were grouped under a single dimension in this study, which was named as 'spatial atmosphere'. The second dimension, which was originally named 'social service environment', called in this study as 'service atmosphere'.

The results obtained by regression analysis both for Turkish and British visitors of Topkapi Palace showed that service and spatial atmospherics had a positive effect on overall visitor satisfaction. Moreover, spatial atmosphere had a higher effect on satisfaction than service atmosphere, for both groups. These findings show similarity with Bonn et al.'s (2007) findings. Based on these results, heritage site authorities may be recommended to give importance to the use of colour scheme, functional layout, lighting, signage issues with the aim of enhancing quality of visitor experience and level of overall satisfaction. It was also suggested in the literature that site atmospherics and its additional components such as good lighting, signage, audio tours, etc. should be designed and controlled by professional perspectives. If these factors are managed effectively, visitor experiences and overall satisfaction are expected to be increased (Bonn et al., 2007; Dietsch, 1997)

In addition, crowding perceptions of both groups were found to have a negative effect on satisfaction, albeit not strongly. In an earlier study on retail crowding and customer satisfaction, Eroglu et al. (2005) obtained similar findings. However, in another study about crowding perceptions and visitor satisfaction at festivals, Kim et al. (2016) exhibited that perceived crowding had a positive effect on satisfaction. Therefore, it can be concluded that the effect of crowding on visitor satisfaction may vary depending on research settings, examined tourism types, and nationalities of the visitors. Although, crowding perceptions of Turkish and British visitors were shown similarity in this study, in the future studies, researchers are recommended to investigate visitors' crowding perceptions at different cultural heritage sites and to measure its impact on behavioural intentions.

The research model was verified by regression and correlation analyses. This study has made a contribution to improve prediction models and relationship research models of visitor satisfaction in cultural areas. It was explored that atmospherics have a positive impact 
on visitor satisfaction while perception of crowding have a negative impact. Besides, crowding perception and atmospherics are negatively correlated.

There are also some limitations to this study that should be mentioned. Firstly, targeting just Turkish and British visitors as the research sample can be considered as a limitation, while visitors from the other countries were ignored. That fact limits the generalization of the obtained findings. Secondly, field research was performed in the period of August-September, 2016 when Topkapi Palace reach to its highest monthly visitor numbers. It was, therefore, impossible for the authors to make high and low tourism season comparisons in terms of perceived site atmospherics and crowding. In the future studies, researchers are encouraged to investigate site-related perceptions of visitors coming from different countries, and to compare the results of this study with their findings that they may obtain at other cultural sites.

\section{Acknowledgement}

This article is based on a master's thesis completed in December, 2016 by Doğuş Kilıçarslan at Akdeniz University in Antalya-Turkey, at Social Sciences Institute, Tourism Management Programme under the direction of Meltem Caber.

\section{References}

Anderson, E. W., Fornell, C., \& Lehmann, D. R. (1994). Customer satisfaction, market share, and profitability: Findings from Sweden. Journal of Marketing, 58(3), 53-66.

Ayala, H. (1996). Resort ecotourism: A paradigm for the 21st century. Cornell Hotel and Restaurant Administrative Quarterly, 37(5).

Baker, J. (1986). The role of environment in marketing services: The consumer perspective. J. A. Czpeil, C. Congam, \& J. Shanaham (Edts), In The Services Marketing Challenge: Integrated for Competitive Advantage (pp. 79-84). Chicago: American Marketing Association.

Bitner, M. J. (1992). Servicescapes: the impact of physical surroundings on customers and employees. Journal of Marketing, 56, 57-71.

Bonn, M. A., Joseph-Mathews, S. M., Dai, M., Hayes, S., \& Cave, J. (2007). Heritage/cultural attraction atmospherics: Creating the right environment for the heritage/cultural visitor. Journal of Travel Research, 45, 345-354.

Bosque, I. R., \& Martín, H. S. (2008). Tourist satisfaction: A cognitive-affective model. Annals of Tourism Research, 35(2), 551-573.

Brown, P. J. (1988). Quality in recreation experience. A. H. Watson (Edts), In Outdoor recreation benchmark: Proceedings of the National Recreation Forum (pp. 412-421). Asheville: US Forest Service.

Büyüköztürk, Ş. (2016). Handbook for Data Analysis in Social Sciences Ankara: Pegem. 
Churchill, G. (1979). A paradigm for developing better measures for marketing contrasts, Journal of Marketing Research, 16, 64-73.

Cole, D. (2001). Visitor use density and wilderness experiences: A historical review of research. W. Freimund, \& D. Cole (Edts) In Proceedings of the visitor use density and wilderness experience (pp. 11-20). Ogden: US Department of Agriculture, Forest Service, Rocky Mountain Research Station.

Desor, J. (1972). Toward a psychological theory of crowding. Journal of Personality and Social Psychology, 21(1), 79-83.

Dietsch, D. K. (1997). Museum boom. Architecture, 86(12), 11-12.

Eroglu, S., Machleit, K., \& Barr, T. (2005). Perceived retail crowding and shopping satisfaction: the role of shopping values. Journal of Business Research, 58(8), 1146-1153.

Evans, J. R., \& Berman, B. (1995). Principles of Marketing (1th Edition). New Jersey: Prentice Hall.

Fakharyan, M., Omidvar, S., Khodadadian, M. R., \& Vosta, L. N. (2014). Examining the effect of customer-to-customer interactions on satisfaction, loyalty, and word-ofmouth behaviors in the hospitality industry: The mediating role of personal interaction quality and service atmospherics. Journal of Travel \& Tourism Marketing, 31(5), 610-626.

George, D., \& Mallery, P. (2010). SPSS for Windows Step by Step: A Simple Guide and Reference, 17.0 Update. Allyn \& Bacon.

Graefe, A. R., Vaske, J. J., \& Kuss, F. R. (1984). Social carrying capacity: An integration and synthesis of twenty years of research. Leisure Sciences: An Interdisciplinary Journal, 6(4), 395-431.

Hui, M., \& Bateson, J. (1991). Perceived control and the effects of crowding and consumer choice on the service encounter. Journal of Consumer Research, 14, 404-420.

Kaya, N., \& Weber, M. J. (2003). Cross-cultural differences in the perception of crowding and privacy regulation: American and Turkish students. Journal of Environmental Psychology, 23, 301-309.

Kim, D., Lee, C.-K., \& Sirgy, M. J. (2016). Examining the Differential Impact of Human Crowding Versus Spatial Crowding on Visitor Satisfaction at a Festival. Journal of Travel \& Tourism Marketing, 33(3), 293-312.

Kotler, P. (1973). Atmospherics as a marketing tool. Journal of Retailing, 49(4), 48-64.

Kozak, M., \& Rimmington, M. (2000). Tourist satisfaction with Mallorca, Spain, as an offseason holiday destination. Journal of Travel Research, 38, 260-269.

Kuo, I.-L. (2002). The effectiveness of environmental interpretation at resource-sensitive tourism destinations. International Journal of Tourism Research, 4, 87-101. 
Lee, R. G. (1977). Alone with others: The paradox of privacy in wilderness. Leisure Sciences, 1(1), 3-19.

Machleit, K., Eroglu, S., \& Mantel, S. (2000). Perceived retail crowding and shopping satisfaction: What modifies this relationship? Journal of Consumer Psychology, 9(1), 29-42.

Mannell, R. C., \& Kleiber, D. (1977). A Social Psychology of Leisure. Pennsylvania: Venture Publication.

Manning, R. (1999). Studies in Outdoor Recreation: Search and Research (2th Edition). Corvallis: Oregon State University Press.

Manning, R., Valliere, W., Minteer, B., Wang, B., \& Jacobi, C. (2000). Crowding in parks and outdoor recreation. Journal of Park and Recreation, 18, 57-72.

McArthur, S. (1994). Acknowledging a symbiotic relationship: better heritage management via better visitor management. Australian Parks and Recreation, 30(3), 12-17.

Moon, H., Yoon, H. J., \& Han, H. (2017). The effect of airport atmospherics on satisfaction and behavioral intentions: Testing the moderating role of perceived safety. Journal of Travel \& Tourism Marketing, 34(6), 749-763.

Moscardo, G. (1999). Making Visitors Mindful: Principles for Creating Quality Sustainable Visitor Experiences through Effective Communication. Urbana: Sagamore.

Neuts, B., \& Nijkamp, P. (2012). Tourist crowding perception and acceptability in cities: An Applied modelling study on Bruges. Annals of Tourism Research, 39(4), 2133-2153.

Nykiel, R. (1997). Enhancing quality through diversity. Journal of Hospitality \& Leisure Marketing, 4(4), 65-70.

Obermiller, C., \& Bitner, M. (1984). Store atmosphere: A peripheral cue for product evaluation. In American Psychological Association Annual Conference Proceedings (pp. 5253). Washington, DC: American Psychological Association.

Orams, M. (1996). A conceptual model of tourist- wildlife interaction: The case for education as a management strategy. Australian Geographer, 27(1), 39-51.

Özmen, A. (2006). Sampling- Unit 7. 7. In the Statistics, A. F. Yüzer (Edts) (p. 177). Eskisehir: Anadolu University.

Prayag, G., \& Chiappa, G. D. (2016). Antecedents of heritage tourists' satisfaction: The role of motivation, discrete emotions and place attachment. In University of Massachusetts 2016Conference Proceedings (pp. 1-4). Amherst: The Canadian Chapter of the Travel and Tourism Research Association.

Rathnayake, R. M. (2015). How does 'crowding' affect visitor satisfaction at the Horton Plains National Park in Sri Lanka? Tourism Management Perspectives, 16, 129-138. 
Republic of Turkey Ministry of Culture and Tourism Topkap1 Palace Museum Directorate (2016). Retrieved from http://www.topkapisarayi.gov.tr/tr/tarih\%C3\%A7e, in 20 November, 2016.

Rojas, C. d., \& Camarero, C. (2007). Visitors' expreience, mood and satisfaction in a heritage context: Evidence from an interpretation center. Tourism Management, 29, 525-537.

Shelby, B. (1980). Crowding models for backcountry recreation. Land Economics, 56(1), 4355 .

Shelby, B., Vaske, J., \& Heberlein, T. (1989). Comparative analysis of crowding in multiple locations: Results from fifteen years of research. Leisure Sciences, 11, 269-291.

Stokols, D. (1972). On the distinction between density and crowding: Some implications for future research. Psychological Review, 79(3), 275-278.

Stokols, D., Rall, M., Pinner, B., \& Schopler, J. (1973). Physical, social, and personal determinants of the perception of crowding. Environment and Behavior, 5, 87-115.

Tabachnick, B., \& Fidell , L. (2003). Using Multivariate Statistics (6 b.). Boston: Pearson.

Tian-Cole, S., \& Cromption, J. (2003). A conceptualization of the relationships between service quality and visitor satisfaction, and their links to destination selection. Leisure Studies, 22(1), 65-80.

Tombs, A., \& McColl-Kennedy, J. R. (2003). Social-servicescape conceptual model. Marketing Theory, 3(4), 447-475.

Tseng, Y.-P., Kyle, G. T., Shafer, C. S., Graefe, A. R., Bradle, T. A., \& Schuett, M. A. (2009). Exploring the crowding-satisfaction relationship in recreational boating. Environmental Management, 43, 496-507.

Wu, H.-C., \& Li, T. (2015). An empirical study of the effects of service quality, visitor satisfaction, and emotions on behavioral intentions of visitors to the museums of Macau. Journal of Quality Assurance in Hospitality \& Tourism, 16(1), 80-102.

Yildirim, K., \& Akalin-Baskaya, A. (2007). Perceived crowding in a cafe/restaurant with different seating densities. Building and Environment, 42, 3410.

Zehrer, A., \& Raich, F. (2016). The impact of perceived crowding on customer satisfaction. Journal of Hospitality and Tourism Management, 29, 88-98.

\section{Doğuş Kiliçarslan}

Akdeniz University, Social Sciences Institute, Doctoral Student at Tourism Management Programme. Postal address: Dumlupinar Boulevard-Campus. Antalya-Turkey.

doguskilicarslan@akdeniz.edu.tr 
Doğuş Kılıçarslan was awarded a Master of Science degree at Akdeniz University, Social Sciences Institute, Tourism Management and Hospitality Programme. He is currently a $\mathrm{PhD}$ candidate at the same programme. His research interests are tourism marketing, tourist guidance, heritage tourism, destination marketing, service quality, and tourism experience. He has published conference papers and articles in tourism and travel journals.

\section{Dr. Meltem Caber}

Akdeniz University, Faculty of Tourism, Tourism Guidance Programm, Dumlupinar Boulevard-Campus. Antalya-Turkey.

meltemcaber@akdeniz.edu.tr

Dr. Meltem Caber works as an associate professor at Akdeniz University, Tourism Faculty, Tourism Guidance Department. She completed her PhD from Akdeniz University, Social Sciences Institute, Tourism Management Programme. Her research interests are tourist behaviour, e-CRM, service quality, and destination management. In some of the well-known scientific journals, she is currently taking part as a reviewer. In previous years, she had also the co-editor and guest editor experiences in the some journals. She has several published international conference papers and refereed articles about tourism marketing and management.

\section{Appendix 1. Survey Form}


Dear participants,

This survey is carried out to investigate the relationship between perceptions of visited places and visitor satisfaction in the context of cultural tourism. The information you have given, is only to be used for scientific purposes, it will be reserved against third parties. Thank you for your attention.

\begin{tabular}{|c|c|c|c|c|}
\hline \multicolumn{2}{|l|}{ Gender } & [ ] Male & [ ] Female & \\
\hline \multicolumn{2}{|l|}{ Nationality } & …………...... & Age & ......... \\
\hline \multicolumn{2}{|c|}{ Marital status } & [ ] Married & [ ] Single & \\
\hline \multirow{2}{*}{$\begin{array}{l}\text { Profession } \\
\text { (Job) }\end{array}$} & \multicolumn{2}{|c|}{ [ ] Private company employee } & [] Employer & [] Student \\
\hline & \multicolumn{2}{|l|}{ [ ] Officer } & [ ] unemployed & [ ] Other........... \\
\hline \multirow{2}{*}{\multicolumn{2}{|c|}{ Education level }} & [] Primary school & [ ] Middle School & [ ] Other............ \\
\hline & & [ ] High school & [] University & \\
\hline \multirow{3}{*}{\multicolumn{2}{|c|}{$\begin{array}{l}\text { Average household } \\
\text { income (Monthly) }\end{array}$}} & [ ] 1-1000f & [ ] 3001-4000f & \\
\hline & & [ ] 1001-2000f & [ ] 4001-5000f & \\
\hline & & [ ] 2001-3000f & [ ] $5001 \mathrm{f}$ and higher & \\
\hline \multirow{3}{*}{\multicolumn{2}{|c|}{$\begin{array}{l}\text { The source of information } \\
\text { that you used for plan your } \\
\text { trip (You can select more } \\
\text { than one option) }\end{array}$}} & [ ] Travel agency & [] Newspaper & [] Television \\
\hline & & Ir [ ] Friends & [ ] Past experiences & [] Journal \\
\hline & & [ ] Internet & [ ] Other............ & \\
\hline \multicolumn{2}{|c|}{$\begin{array}{l}\text { How many times have } \\
\text { you visited Turkey? } \\
\text { (Including this one) } \\
\end{array}$} & 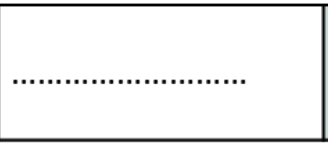 & $\begin{array}{l}\text { How many times have } \\
\text { you visited İstanbul? } \\
\text { (Including this one) } \\
\end{array}$ & $\ldots \ldots \ldots \ldots \ldots \ldots \ldots$ \\
\hline \multicolumn{2}{|c|}{$\begin{array}{l}\text { Your total stay in } \\
\text { Turkey }\end{array}$} & [ ] .............. days & $\begin{array}{l}\text { How many times have } \\
\text { you visited Topkapi } \\
\text { Palace? (Including this } \\
\text { one) }\end{array}$ & [ ] $\ldots \ldots \ldots \ldots$ \\
\hline \multirow{2}{*}{\multicolumn{2}{|c|}{\begin{tabular}{|l} 
Your information \\
resource about Topkapi \\
Palace (You can select \\
more than one option) \\
\end{tabular}}} & $\begin{array}{l}\text { [ ] Travel agency } \\
\text { [ ] Friends }\end{array}$ & \begin{tabular}{|l} 
[ ] Newspaper \\
[ ] Past experiences
\end{tabular} & \begin{tabular}{|l} 
[ ] Television \\
[ ] Journal
\end{tabular} \\
\hline & & [ ] Internet & [ ] Other............ & \\
\hline
\end{tabular}




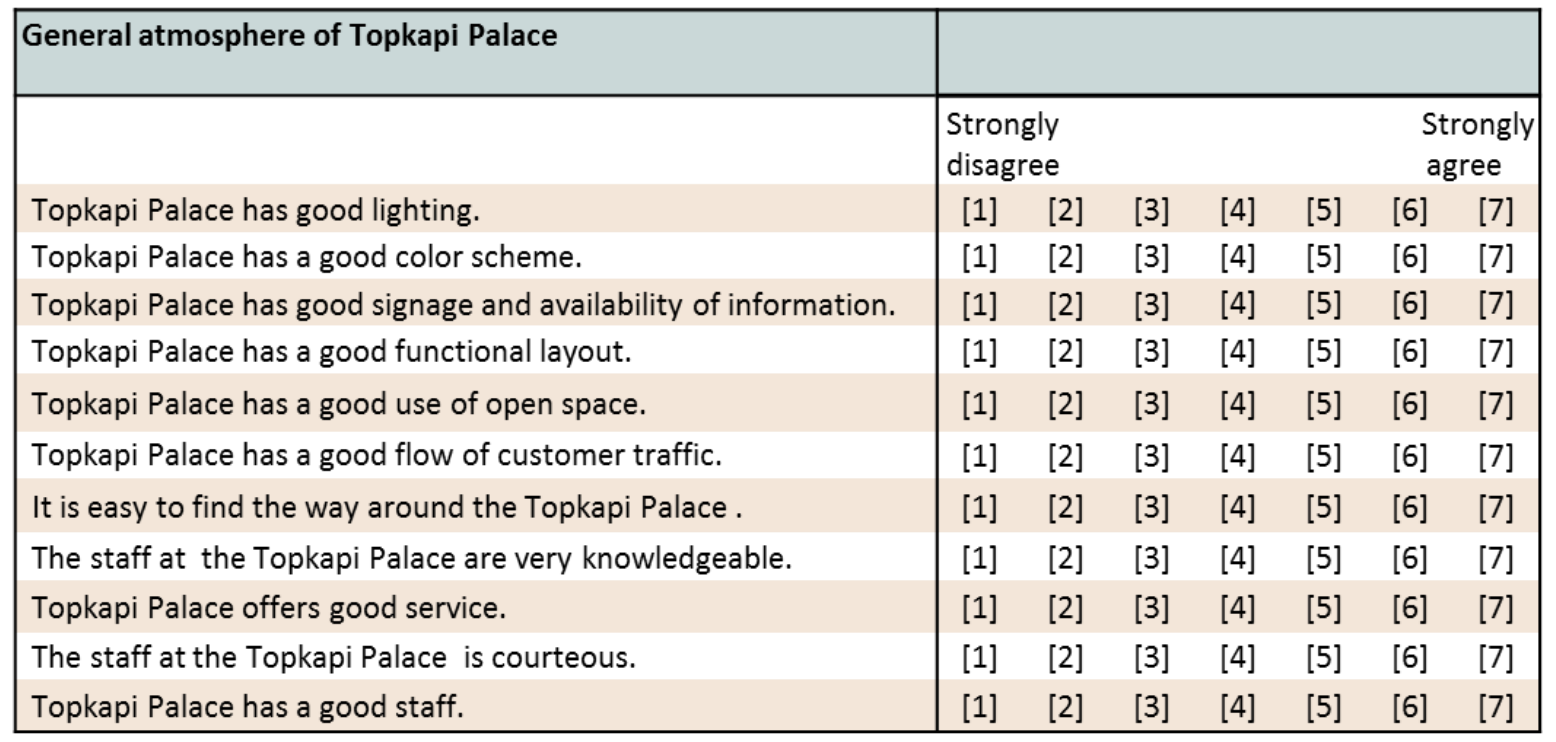

\begin{tabular}{|c|c|c|c|c|c|c|c|}
\hline \multirow[b]{3}{*}{ Topkapi Palace is one of the best palace I could have visited. } & & & & & & & \\
\hline & \multicolumn{5}{|c|}{\begin{tabular}{|l|} 
Strongly \\
disagree
\end{tabular}} & \multicolumn{2}{|c|}{$\begin{array}{l}\text { Strongly } \\
\text { agree }\end{array}$} \\
\hline & & [2] & [3] & [4] & [5] & [6] & [7] \\
\hline I am pleased with my decision to visit Topkapi Palace. & [1] & [2] & [3] & [4] & [5] & [6] & [7] \\
\hline I have really had a good time, I have had fun in this center & [1] & [2] & [3] & [4] & [5] & [6] & [7] \\
\hline I will recommend someone to visit Topkapi Palace. & [1] & [2] & [3] & [4] & [5] & [6] & [7] \\
\hline I will say positive things about Topkapi Palace. & [1] & [2] & [3] & [4] & [5] & [6] & [7] \\
\hline
\end{tabular}

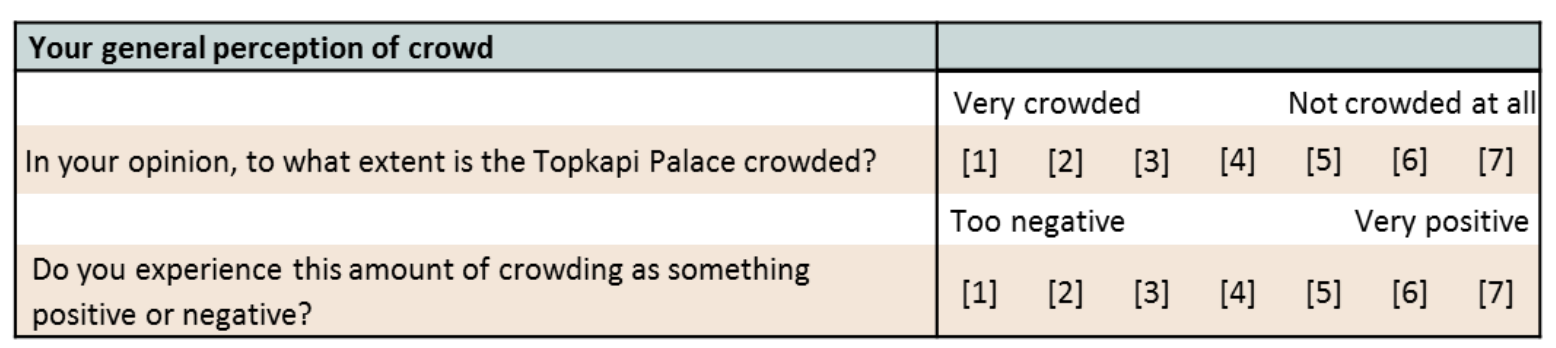

Source: Authors 